\title{
Online Teaching: Model and Perspective in Arabic Class
}

\author{
Dessy Suryawati ${ }^{1, *}$ Nuril Mufidah ${ }^{2}$
}

\author{
${ }^{1}$ Pascasarjana UIN Maulana Malik Ibrahim Malang, Indonesia \\ ${ }^{2}$ UIN Maulana Malik Ibrahim Malang, Indonesia \\ *Corresponding author. Email: dessysuryawati2017@gmail.com
}

\begin{abstract}
Online learning carried out in the new normal era provides opportunities for the academic community to analyze technology for learning better. This online system is implemented starting from campus introduction activities for new students, library access to lecturing activities. This research used a qualitative descriptive method of case study type, with new students of the post-graduate program of Arabic Language Education in the 2020 academic year of UIN Maulana Malik Ibrahim Malang, Indonesia. The data collection techniques used observation, interviews, and online surveys, and the data were analyzed by triangulation. This research focuses on the process of campus cultural orientation for the first-year student, the implementation of post-graduate lectures, and new students' perspective on the lecture during the new normal. The results of this study indicate that the campus cultural orientation for new students in the 2020 academic year is carried out using an online system. The lecture and lecturers' delivery of material is carried out online using e-learning media, zoom meet, google meet, and WhatsApp application. Presentations from students through the zoom meet application and WhatsApp application. Presentation of students prefers zoom meet 53.8\%, the learning model that is done when online lectures students prefer learning with a zoom presentation of $76.9 \%$. Learning and material delivery by student lecturers was more favorable in learning videos, reaching 38.5\%. In general, $69.2 \%$ of students felt helped by the application of online lectures, and on the other hand, $30.8 \%$ felt that they were not helped. Online teaching for postgraduate students with a discussion model using online media is preferred by students and can be used as alternative teaching to deal with a pandemic.
\end{abstract}

Keywords: New Normal Learning, Online Learning, Arabic, Postgraduate, Online, Perspective

\section{INTRODUCTION}

Education has a significant role. Law No. 20 of 2003 concerning the National Education System in Article 3, states that national education aims to develop capabilities and shape noble national character and civilization. National education aims to develop students' potential so that they become human beings who believe and fear God Almighty, have a noble character, are healthy, knowledgeable, capable, creative, independent, and become democratic and responsible citizens [1].

Based on national education's functions and objectives, it is clear that education at every level must be organized systematically to achieve these goals. However, the Covid 19 pandemic that hit various parts of the world, including
Indonesia, impacted the learning system's transfer from face-to-face to an online or online system [2].

Our country is currently facing the COVID 19 virus pandemic, and currently, the government is implementing a new normal policy that has implications for the education sector so that students are asked to study at home to avoid exposure to COVID 19. Educators and students must learn online or online, so there is no face to face class as usual. Of course, incidents like this require students and educators to learn and learn online or online or remotely but with the achievement and educational goals that remain of high quality and quality.

Maulana Malik Ibrahim State Islamic University Malang is one of the Islamic Religious Colleges with a passion for producing graduates who have Spiritual Depth, Moral Greatness, Extent of Knowledge, and 
Professional Maturity. In learning in this new normal era, UIN Malang responds to government regulations to implement online learning programs. This online learning system becomes a challenge for UIN Malang in order to achieve national education goals systematically Not only the delivery of material in learning uses an online system, but some access to campus facilities also uses an online system such as a library, thesis trial, a series of exams to get to student graduation. Apart from providing an online learning experience, the application of an online system on campus has also caused various complaints about students, especially new students who have just adapted to the campus environment. Study Orientation and Campus Introduction activities previously held face-to-face are now being carried out online through google meet. For new students with the introduction of University through the online system, it produces different outputs with a different understanding of the campus system and introduction of study programs.

New students of Post-graduate Arabic language education at UIN Malang do a class division system not by going through the academic information system page but determining for themselves what class and what day to take courses, class selection, and learning schedules are carried out very flexible, namely by using the Android application, namely Whatsapp application.

The implementation of the study and campus introduction is very flexible, including the online learning model. However, every new student assesses this flexibility with a different perspective, including its impact on the effectiveness of learning in this new normal era using an online system.

This research was conducted to find out how the process of the new student's graduate program in the New Normal era, how the implementation of lectures for new post-graduate students, and how the perspective of new students towards the lecture model from the new normal era.

\section{METHOD}

Online Learning Research in the perspective of new Arabic language education students at UIN Malang Postgraduate uses a qualitative descriptive approach, support the object of research, then analyzing these factors to look for its role [3]. Qualitative research is a research that involves analyzing and interpreting texts and interviews in order discover meaningful patterns descriptive of a particular phenomenon [4].

The subjects of this study are 13 students of Arabic language education at UIN Malang Postgraduate Class B. Retrieval of data through 1) Observation about the process of new students of Arabic Education Postgraduate UIN Malang, 2) Observation of the online lecture process in class B new students of post-graduate Arabic education 3) Interviews of students of the new students of Arabic Language Education Postgraduate Program in UIN Malang class B about online learning that has been passed.
The collected data is processed by triangulation, reduction, data presentation, and concluding (Prabowo, 2013). Triangulation is a data collection technique that combines various data collection techniques and existing data sources. There are three triangulation kinds, namely triangulation with sources, triangulation with techniques, and time triangulation. In this study, the authors used the triangulation of sources by checking the data obtained through interviews. Triangulation is a data collection technique that combines various data collection techniques and existing data sources. There are three triangulations, namely triangulation with sources, triangulation with techniques, and time triangulation. In this study, the authors used the triangulation of sources by checking the data obtained through interviews. In this study, to test the credibility of product-based learning data, the data obtained were tested from the interviews' results adjusted to the theory - the existing theories.

\section{RESULT AND DISCUSSIONS}

\subsection{Study Orientation Process and Campus Introduction in the New Normal Era}

The implementation of OSPEK is based on the Decree of the Director-General of Higher Education Number 38 / DIKTI / Kep / 2000 concerning the Regulation of New Student Admission Activities in Higher Education. OSPEK aims to provide new students with an initial introduction to various aspects of higher education, such as university statutes, academic regulations, curriculum systems, how to study in higher education, student ethics, and student organizations. Besides, these activities can introduce university leaders, faculties, and departments/study programs. Therefore, OSPEK for new students is a significant activity as a gateway to campus life, which is also the first step in introducing and developing the academic culture of the Ministry of Education and Culture of the Republic of Indonesia in decree number 25 / DIKTI / Kep / 2014 regarding General Guidelines for Introduction to Life The Campus for New Students states that the introduction program must be carefully planned so that it can be used as the right moment to instill character education for new students. New students are expected to receive accurate information about the education system in higher education, both academic and nonacademic fields [5].

The implementation of OSPEK for new Post-graduate students is carried out in 2 ways: online through the Zoom Meet application and offline, namely, coming to the Direct Postgraduate Building. OSPEK participants who can attend offline are welcome to come to the association building at Post-graduate Campus 2 UIN Malang, and participants who wish to attend online are welcome to follow through a zoom meeting. Educators such as lecturers, rectors, and staff participated directly in the association building, and new students took part in more of the 
OSPEK Zooom via Meet participants from outside Java or in Java, even those near the campus chose to take Via Online.

In a survey conducted with 13 new post-graduate students majoring in Arabic language education, the number of students stated that $61.5 \%$ felt that the new students' perspective in delivering the material was not clear, $15.4 \%$ was unclear, $23.1 \%$ of the material was evident. The reasons that the delivery of material in OSPEK is not very clear from the perspective of students, including it is not optimal if it is done with an online system because not all regions have internet access, besides that the payment of OSPEK funds is not appropriate with the facilities obtained, ineffective, not conducive. Furthermore, students who feel that the material's delivery is precise is because it helps a little to enter lectures. After all, there is an introduction to campus conditions without yelling between senior students and new students.

\subsection{Implementation of Online Learning system in Lectures}

The form of lectures that can be used as a solution during the Covid-19 pandemic is online learning. Online learning uses internet networks with accessibility, connectivity, flexibility, and the ability to generate various learning interactions. The research stated by Zhang et al. shows that the use of the internet and multimedia technology can change the way of conveying knowledge and can be an alternative to learning carried out in traditional classrooms. According to Kuntarto, online learning enables students and lecturers to carry out learning interactions with the internet's help [6].

At the implementation level, online learning requires mobile devices such as smartphones or Android phones, laptops, computers, tablets, and iPhones, which can access information anytime and anywhere [7].

Online learning, which is carried out in this lecture, has several media, while the media used in this lecture are Whatsapp, Zoom Meet, Google Meet, Google Classroom, E-Learning. Moreover, the learning model carried out by this lecture consists of Presentations Zoom via / Google Meet, Presentations Via the Whatsapp application, making Papers, filling out questions on ELearning. Simultaneously, the form of material presented by the lecturer consists of several ways, namely through video lessons, power points, teleconferences, PDF materials, and audio.

\subsection{New Student Perspectives on Online Learning}

The use of mobile technology has a significant contribution to educational institutions, including distance learning goals. The Postgraduate Program at UIN Malang uses the online system; in this study, the respondents were new graduating students majoring in
Arabic language education in class B. Student perspectives in responding to various online lectures.

In the use of media or applications used during the lecture process, it is explained that the presentation of students who like learning via Whatsapp is $30.3 \%$, likes zoom meet $53.8 \%$, likes Google Classroom7.7\%. It indicates that the most popular presentation is learning via Zoom Meet with the reason that learning can be done face-to-face, although not directly, the learning process is more pronounced because it can communicate directly with lecturers, complete and accessible features.

The learning model carried out during online lectures is through zoom presentations, presentations via WhatsApp groups, making papers, and filling in questions on e-learning. The interested learning model explains that the presentation of students who like learning with the Zoom Presentation is $76.9 \%$. Furthermore, the rest liked the learning model via WhatsApp, with a presentation of $23.1 \%$. The highest presentation is the learning model that is of interest through the zoom meet because it is easy to use, can interact directly, is more effective in lectures, can faceto-face between students and lecturers, and is more efficient it can directly convey ideas and opinions orally.

The lecturer's online learning consists of several methods, namely learning using video lessons, using power points, teleconferences, materials in pdf form, and audio. The number of new students who liked the learning process conveyed by the teacher using the Learning Video reached $38.5 \%$. Powerpoint $14.5 \%$, teleconference $23.1 \%$, pdf material $23.2 \%$.

While overall student reviews about learning in lectures using the online method stated that of the 13 students, $69.2 \%$ felt helped in the online lecturing process, and $30.8 \%$ felt this online lecture did not help them. Students who feel helped by online learning are due to circumstances that are not yet possible to make face-to-face learning because covid-19 and online learning are alternatives to keep learning. Others argue that online learning can help allocate time for family and work. Moreover, some reviews for those who feel that online learning does not help in lectures is that online learning is not better than direct learning because students are more focused on learning, and lecturers are more maximized in delivering material.

\section{CONCLUSION}

The introduction of university culture for new postgraduate programs in the new normal era is done online. With material introducing university culture, introduction to majors, and class division Online Learning, which is carried out in this lecture, has several media, while the media used in this lecture are Whatsapp, Zoom Meet, Google Meet, Google Classroom, E-Learning. Moreover, the learning model carried out by this lecture consists of Presentations Via 
Zoom / Google Meet, Presentations Via the Whatsapp application, making Papers, filling out questions on ELearning. Simultaneously, the form of material presented by the lecturer consists of several ways, namely through video lessons, power points, teleconferences, PDF materials, and audio.

This Online Learning stated that of the 13 female students, $69.2 \%$ felt helped in the online lecture process, and $30.8 \%$ felt this online lecture did not help them.

\section{REFERENCES}

[1] M. Walid, Model Pendidikan Karakter di Perguruan Tinggi Agama Islam: Studi tentang Pendidikan Karakter Berbasis Ulul Albab di Universitas Islam Negeri Maulana Malik Ibrahim Malang, El Qudwah, 4 (2011)115-156.

[2] A.I. Rafsanjani, Kebijakan Pendidikan di Era New Normal, 2020 , DOI: https://doi.org/10.31219/osf.io/29v6a
[3] Arikunto, Prosedur Penelitian: Suatu Pendekatan Praktik, Jakarta: Rineka Cipta, 2010

[4] Sugiyono, Metode Penelitian Kualitatif (3rd ed.), Bandung: Alfabeta, 2017

[5] D. Pramono, Model Program Pengenalan Kampus Untuk Mengembangkan Kesiapan Karir Mahasiswa, in Prosiding Seminar Nasional Pagelaran Pendidikan Dasar Nasional (PPDN), 308, 2019.

[6] A. Sadikin, A. Hamidah, Pembelajaran Daring di Tengah Wabah Covid-19 (Online Learning in the Middle of the Covid-19 Pandemic), BIODIK: Jurnal Ilmiah Pendidikan Biologi, 6(2) (2020) 214-224.

DOI: https://doi.org/10.22437/bio.v6i2.9759

[7] J. Gikasa, M. M.Grant, Mobile Computing Devices in Higher Education: Student Perspectives on Learning with Cellphones, Smartphones \& Social Media, The Internet and Higher Education, 19 (2013) 18-26, DOI: https://doi.org/10.1016/j.iheduc.2013.06.002 